\title{
Contact dermatitis and other skin conditions in instrumental
} musicians

\author{
Thilo Gambichler*1, Stefanie Boms² and Marcus Freitag²
}

Address: ${ }^{1}$ Dermatology Out-Patient Clinic, Oldchurch Hospital, Waterloo Road Romford, RM7 OBE, London, United Kingdom and ${ }^{2}$ Department of Dermatology and Allergology, Ruhr-University Bochum Gudrunstr. 56, D-44791 Bochum, Germany

Email: Thilo Gambichler* - thilo@gambichler.freeserve.co.uk; Stefanie Boms - bomss@gmx.net; Marcus Freitag - m.freitag@derma.de

* Corresponding author

Published: 16 April 2004

BMC Dermatology 2004, 4:3

This article is available from: http://www.biomedcentral.com/I47I-5945/4/3

(C) 2004 Gambichler et al; licensee BioMed Central Ltd. This is an Open Access article: verbatim copying and redistribution of this article are permitted in all media for any purpose, provided this notice is preserved along with the article's original URL.
Received: 30 January 2004

Accepted: 16 April 2004

\begin{abstract}
Background: The skin is important in the positioning and playing of a musical instrument. During practicing and performing there is a permanent more or less intense contact between the instrument and the musician's skin. Apart from aggravation of predisposed skin diseases (e.g., atopic eczema or psoriasis) due to music-making, specific dermatologic conditions may develop that are directly caused by playing a musical instrument.
\end{abstract}

Methods: To perform a systematic review on instrument-related skin diseases in musicians we searched the PubMed database without time limits. Furthermore we studied the online bibliography "Occupational diseases of performing artist. A performing arts medicine bibliography. October, 2003" and checked references of all selected articles for relevant papers.

Results: The most prevalent skin disorders of instrumental musicians, in particular string instrumentalists (e.g., violinists, cellists, guitarists), woodwind players (e.g., flautists, clarinetists), and brass instrumentalists (e.g., trumpeters), include a variety of allergic contact sensitizations (e.g., colophony, nickel, and exotic woods) and irritant (physical-chemical noxae) skin conditions whose clinical presentation and localization are usually specific for the instrument used (e.g., "fiddler's neck", "cellist's chest", "guitar nipple", "flautist's chin"). Apart from common callosities and "occupational marks" (e.g., "Garrod's pads") more or less severe skin injuries may occur in musical instrumentalists, in particular acute and chronic wounds including their complications. Skin infections such as herpes labialis seem to be a more common skin problem in woodwind and brass instrumentalists.

Conclusions: Skin conditions may be a significant problem not only in professional instrumentalists, but also in musicians of all ages and ability. Although not life threatening they may lead to impaired performance and occupational hazard. Unfortunately, epidemiological investigations have exclusively been performed on orchestra musicians, though the prevalence of instrument-related skin conditions in other musician groups (e.g., jazz and rock musicians) is also of interest. The practicing clinician should be aware of the special dermatologic problems unique to the musical instrumentalist. Moreover awareness among musicians needs to be raised, as proper technique and conditioning may help to prevent affection of performance and occupational impairment. 


\section{Background}

Apart from musculoskeletal problems (e.g., tendosynovitis) and neurological disorders (e.g., focal dystonia), instrumental musicians are also a risk group for a variety of skin conditions, since an intense contact between the instrument and the musicians's skin is usually necessary during music-making [1-4]. In a recent survey on 117 musicians working in a professional orchestra a significant incidence of occupational and stress-related skin problems such as hyperhidrosis, lichen planus, psoriasis, eczema, and urticaria has been observed [5]. It is well known that performing artists, in particular instrumental solists, are exposed to enormous psychological stress [15]. Thus emotional factors may significantly trigger common idiopathic or genetically predisposed skin disorders in the musician as well. However professional and amateur musicians may suffer not only from common skin diseases of the population at large, but also conditions that are a direct result of their work and hobby, respectively. Generally, large epidemiological studies among performing artists have failed to look at skin disorders [4]. However in a small survey of 24 symphony orchestra members, mechanically caused skin conditions were the most frequent findings that were directly associated with the instrumental performance [7]. Nethercott and Holness confirmed these results in their survey on 41 orchestra players [6]. Furthermore Önder et al. [12] surveyed 97 orchestra musicians, three of them had allergic contact dermatitis related to their instrument. All in all, a variety of irritant as well as allergic skin conditions has previously been described in numerous brief case observations [612]. For the present comprehensive review, we have systematically searched the medical and musical literature to identify the dermatologic problems of musical instrumentalists.

\section{Methods}

We searched the PubMed database (includes citations from Medline and additional life science journals) without time limits for skin disorders in instrumental musicians http://www.ncbi.nlm.nih.gov/entrez/ query.fcgi? $\mathrm{db}=$ PubMed. The following key words were used: skin diseases; musicians; skin disorders; allergy; instrumental music; musical instruments. Furthermore we studied the regularly updated website "Occupational diseases of performing artist. A performing arts medicine bibliography. October, 2003" http://www.sailor.lib.md.us/topics/ music/art med 03.htm. A careful review of all references cited in the selected articles was performed as well. Only relevant articles such as original papers, case reports, letters, reviews and book articles were included.

\section{Results \\ Allergic contact dermatitis Colophony}

There are numerous case observations of allergic contact dermatitis to unmodified colophony in instrumental musicians, in particular string players such as violinists and cellists [13-19]. Colophony dust may cause dermatitis of the fingers and hands, as well as of the face and neck. In 1930 Ramirez and Eller [13] first described a chronic fissured hand dermatitis of a violinist who applied colophony to the bow of his instrument. Wahlberg [14] found that 6 of 15 musicians allergic to colophony were also allergic to abietic acid. Colophony also known as rosin (INCI no. 280-192-2) is a naturally occurring material obtained from different species of coniferous tree (family Pinaceae). It is a complex mixture of resin acids and neutral substances. Abietic acid and its derivates are however thought to be the principal sensitizers of colophony $[15,16]$. Unmodified colophony is commonly used by string players (e.g., violin, viola, cello) to wax the strings in order to increase the attrition between the bow and the strings. There are many brands of colophony with various ingredients, so string players with sensitivities should find a different colophony that is better tolerated. For example, Nethercott and Holness [6] reported a 63-year-old male violinist with a 5-year history of an eczematous eruption on the left side of his neck. Patch testing revealed a strong reaction to colophony, both $20 \%$ and $60 \%$ in petrolatum. Despite his attempts to use as little colophony as possible, the eruption continued. In this case combination of fiddler's neck (see next paragraph) and colophony allergy was however likely. A musician may be exposed to colophony in numerous products including adhesive tapes, furniture polish, cosmetics, and varnishes as well. Moreover cross-reactions between turpentine, chrysanthemum, and balsam of Peru are well known.

\section{Nickel sulphate}

Nickel, a common metal, is the most frequent contact sensitizer in the population at large. Nickel sensitivity has been observed in $4.5 \%$ in the general population, in $8 \%$ of females and $0.8 \%$ of males $[20,21]$. It plays a great role in contact dermatitis of musicians, as well, and may cause dermatitis of the fingers and hands, as well as of the lip and neck area. Nickel contact dermatitis has been reported in string players (e.g., violinists, cellists, guitarists) and wind and brass instrumentalists such as flautists and trumpet players [22-31]. Woodwind or brass instrumentalists with nickel allergy may switch to gold or plastic mouthpieces. The release of nickel from metal devices is favored by friction, heat or galvanic factors. This may also happen during exposure to various bodily fluids including sweat and saliva. Consequently chronic mechanical irritation and maceration may not only cause irritant dermatitis but can also promote allergic contact eczema. 
Combined reactions to nickel, and chromium are not uncommon in the population at large and do present a simultaneous, distinct, and specific sensitization.

Marshman and Kennedy [24] reported a classic guitar player who experienced a dermatitis of the fingers due to a combined allergy to nickel and metal guitar strings. Notably, this affluent patient substituted 24-karat gold strings. Bronze, copper, nylon, or organic strings are available for less affluent, nickel-sensitive acoustic string instrumentalist. However there are not much alternatives for the common electric guitar or bass player who usually uses nickel-wound and stainless steel strings which are characterized by optimal electromagnetic properties (Fig. 1). Stainless steel used for thin strings such as the E-string of a violin or guitar is basically an iron-chromium solid solution alloy with nickel and other ingredients added to increase resistance to corrosion and pitting. Fisher [27] described a patient with an allergic cheilitis from nickelplated harmonica. The patient had a strongly positive patch test reaction to nickel sulphate and the metallic parts of the instrument showed a strongly reaction to the dimethylglyoxamine test. Furthermore Ingue et al. [22] reported a 19-year-old female flautist who developed eczema on her chin 2 months after developing earlobe dermatitis from an earring. Inductively coupled plasma atomic emission spectrometry revealed that her flute contained $0.067 \%$ nickel, though a dimethylglyoxamine spot test on the flute was negative. Patch tests showed a positive reaction to $2.5 \%$ nickel sulphate in petrolatum. The authors discussed that their case was due to nickel sensitivity of the alloy enhanced by pressure, friction, and moisture of sweat, breath condensation and saliva. Accordingly, Moreno et al. [31] described a 24-year-old viola player who had developed allergic contact dermatitis to nickel that was contained in metal pieces of the chin rest - a similar case has also been reported by Pencelli [25].

\section{Exotic woods}

A variety of exotic woods are present in musical instruments and may cause allergic contact dermatitis [32-39]. East Indian and Brazilian rosewood is used for manufacture of string and reed instruments such as violins, violas, guitars, recorders, and flutes. Makassar ebony and ebony woods are used for crafting violin and guitar fingerboards. Moreover Cocobolo wood and African blackwood are utilized for the production of recorder, oboe, and other reed instruments. For example, Hausen and Mau [35] reported a 19-year-old female violinist who developed an allergic contact dermatitis at her chin corresponding to the site of the wooden chin rest. The timber of the chin rest was identified botanically as an East Indian rosewood species (Dalbergia latifolia Roxb.). Patch tests with compounds of both standard series and ethanol extract of the chinrest wood revealed positive reactions. Accordingly, Haustein [38] described a case of allergic chinrest dermatitis to East Indian rosewood in a violinist. Furthermore Hausen et al. $[32,33,36]$ reported on allergic contact dermatitis in musicians (recorder player, violinist) that was caused by a rosewood substitute Machaerium scleroxylum (Pao ferro), Brazilian rosewood (Dalbergia nigra All), or Cocobolo wood (Dalbergia retusa), respectively. Patients should be advised of cross-sensitivity between similar woods containing structurally related allergens. For example, the sensitizing agent (R)-4-methoxydalbergione is present in Brazilian and East Indian rosewood as well as Cocobolo [37]. For string players, boxtree wood has been recommended as an alternative chin rest wood because it does not contain any known allergens [9].

\section{Cane reed}

Several case reports on cane reed contact allergies in musicians have been reported [40-43]. Ingoue et al. [40] described a 32-year-old man with a 6-month history of severe cheilitis that developed 2 months after starting to play the saxophone for a few hours several times a week. The patient showed scaly erythema with erosions and fissures on the median lower lip, and the distribution matched the area in contact with the saxophone cane reed which was made of the reed grass Arundo donax which is related to bamboo. The stems of the plants are used, for example, as lathes, for fishing rods, or in crafting of wind instruments such as saxophone or clarinette. Accordingly McFadden et al. [41] reported a similar case in a clarinetist who showed the same patch testresults. Apart from irritant contact dermatis, both immediate and delayed allergic aetiologies have been observed in cane reed cheilitis [40-43]. Notably, an immediate-type allergic, contact urticaria-like reaction to a reed made of Arundo donax has been observed in an atopic saxophonist. This patient had a positve prick test but not patch test result [43]. Plastic polysterene reeds are available for wind instrumentalists with cane reed hypersensitivity.

\section{Propolis}

There have been few case reports of allergic contact dermatitis to propolis cera (INCI no. 288-130-6) in musicians and instrument makers [44-47]. Liebermann et al. [44] described a case of a stringed instrument craftsman and violinist who developed allergic contact dermatitis to propolis, a component of Italian varnish. Besides, this patient had positive patch test results to colophony as well. Hausen et al. [46] reported that propolis has been used as an ingredient in violin varnish for centuries. Stradivari is said to have used it in the varnish of his instruments. Propolis, also known as bee glue, is produced by bees during hive construction to fill structural gaps. It has approximately 50 constituents, primarily resins and vegetable balsams (50\%), waxes (30\%), essential 


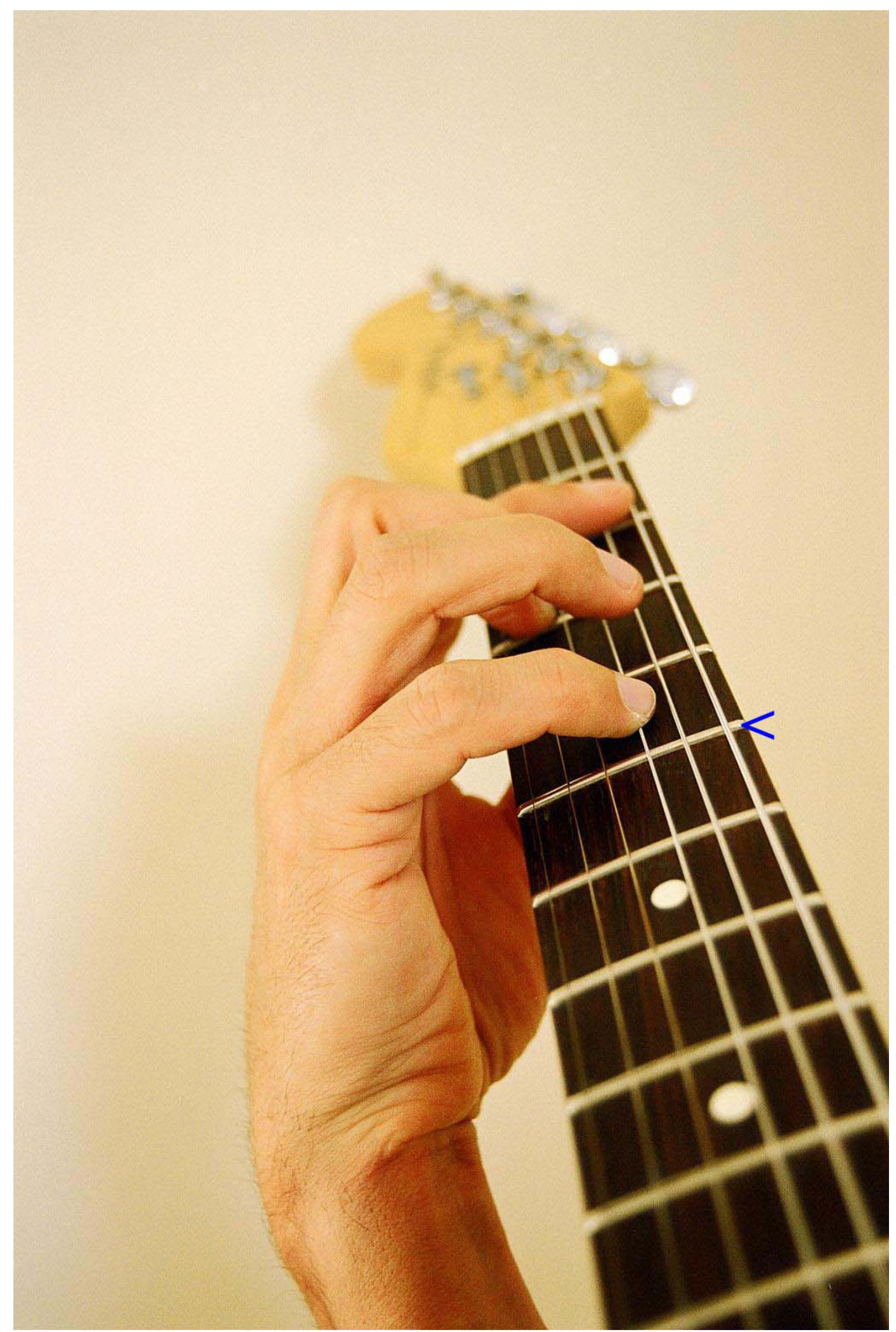

Figure I

Intense skin contact with potentially chromium as well as nickel-sensitizing components on the frets and strings (arrow head) of an electric guitar's neck. 
and aromatic oils (10\%), and pollen (5\%). Since ancient times, this agent has also been incorporated into numerous medical and cosmetic products since it is believed to be a potent antiseptic and anti-inflammatory substance, local anaesthetic, adstringent, and antioxidant. Moreover propolis may be found in toothpaste, mouthwash preparations, facial creams, chewing gum, polishes, and varnishes. Because string players such as violinists and cellists as well as stringed instrument makers may be significantly exposed to propolis in varnish, the differential diagnosis of a recalcitrant, chronic eczema in these individuals must include allergic contact dermatitis [45]. Moreover, patients with an allergy to propolis may be at risk for cross-sensitization with balsam of Peru [47].

\section{Para-phenylenediamine}

Bork [48] described skin eruptions on the neck of a violinist which have been caused by para-phenylenediamine allergy. Chin rests made of ebony wood that are black enough have been coloured with a stain containing "Ursol-Echtschwarz", which consists of para-phenylenediamine, a common allergen with cross-reactivity to parabens, benzocaine, and sulfonamides. Furthermore O'Hagen and Bingham [49] reported a 11-year-old cellist with dermatitis on the right thumb, index and middle finger of her right hand that held the bow. On patch testing she was positive on para-phenylenediamine which was used to stain her bow string.

\section{Potassium dichromate}

Nethercott and Holness [6] reported a 25-year-old harpist with a 5-month history of an eczematous rash on the tips of her fingers on her right hand. Patch testing showed a strong reaction to potassium dichromate. The authors found out that this common allergen was used as a tanning agent for the strings of her harp. Buckley and Rogers [50] described a 30-year-old professional violinist who presented with a 3-year history of hand and foot dermatitis. It started on the left ring finger and spread to both hands and feet. Patch test revealed a strong reaction to potassium dichromate that was contained in the core of the E-string of his instrument. Changing the string to a type with a stainless or aluminium core resulted in rapid clearing of the dermatitis. Trivalent or hexavalent chromium is usually utilized for this purpose. Hexavalent chromium has greater sensitizing properties, since it readily penetrates the skin, in particular in sweaty conditions. As exemplarily demonstrated in Figure 1 and 2, string instrumentalists such as electric guitar and bass players are not only at risk to develop nickel but also chromate allergy due to intense contact to chromated steel components on their instrument (e.g., strings, bridge, frets). Besides chromated leather of instrument accessories such as guitar straps may also play a role in contact dermatitis of musicians $[21,50]$.

\section{Irritant contact dermatitis and related disorders "Fiddler's neck"}

Many case observations have been reported on "fiddler's neck" [51-61]. Peachey and Matthews [51] systematically studied this condition that frequently affects violin and viola players. An area of lichenification and hyperpigmentation on the side of the neck below the angle of the jaw is usually observed in this skin disorder. Erythema, scaling, cyst and scar formation, papules and pustules, and even focal neck oedema may occur as well $[51,56,57]$. Recently dystrophic calcinosis cutis in the skin below the mandible has been described in a 29 -year-old violinist [52]. Histopathology of "fiddler's neck" frequently demonstrates hyperkeratosis, acanthosis and histiocytic infiltrates with presence of granulomas to foreign body and follicular cysts. Clinically, non-eczematous irritant contact dermatitis with granulomatous or acne-like appearance has previously been distinguished. Persistent or "dermal" irritant contact dermatitis may also be differentiated histopathologically from rosacea and sarcoid reaction with granuloma formation [62]. Probably due to the particular location and relatively complex mechanism for causation of "fiddler's neck" the clinical appearance and histopathology of this skin condition show a wider spectrum of skin changes as compared to common irritant contact dermatitis $[50,62]$. Some authors believe that this condition belongs to the range of acne mechanica [53]. The aetiology is thought to be due to a combination of factors: friction giving rise to lichenification, while local pressure, shearing stress, and occlusion may play a part in producing acne-like lesions and cyst formation. Additionally poor hygiene may predispose to local infection. Viola players are believed to be more prone to develop "fiddler's neck" than violinists because the instrument itself is larger and heavier [51,59].

Similar irritant skin disorders such as "cellist's chest" and "cellist's knee" have also been described in cello players $[7,63]$. Even a "cello scrotum" has been described in a brief letter [64]. However this term has been questioned since the contact of the cello's body with the scrotum would require an extremely awkward playing position [65]. Interestingly, Curtis [66] reported three girls with traumatic mastitis of one breast. The condition consisted of a slightly inflamed cystic swelling at the base of the nipple. All three patients were learning to play classic guitar on a full-sized guitar - the edge of the sound-box pressed against the nipple. Consequently the two right-handed patients had a right-sided mastitis and the left-handed patient a left-sided mastitis. This condition, also known as "guitar nipple" can easily be prevented by positioning the adequate instrument properly to reduce the amount of pressure placed on the nipple [67-69]. 


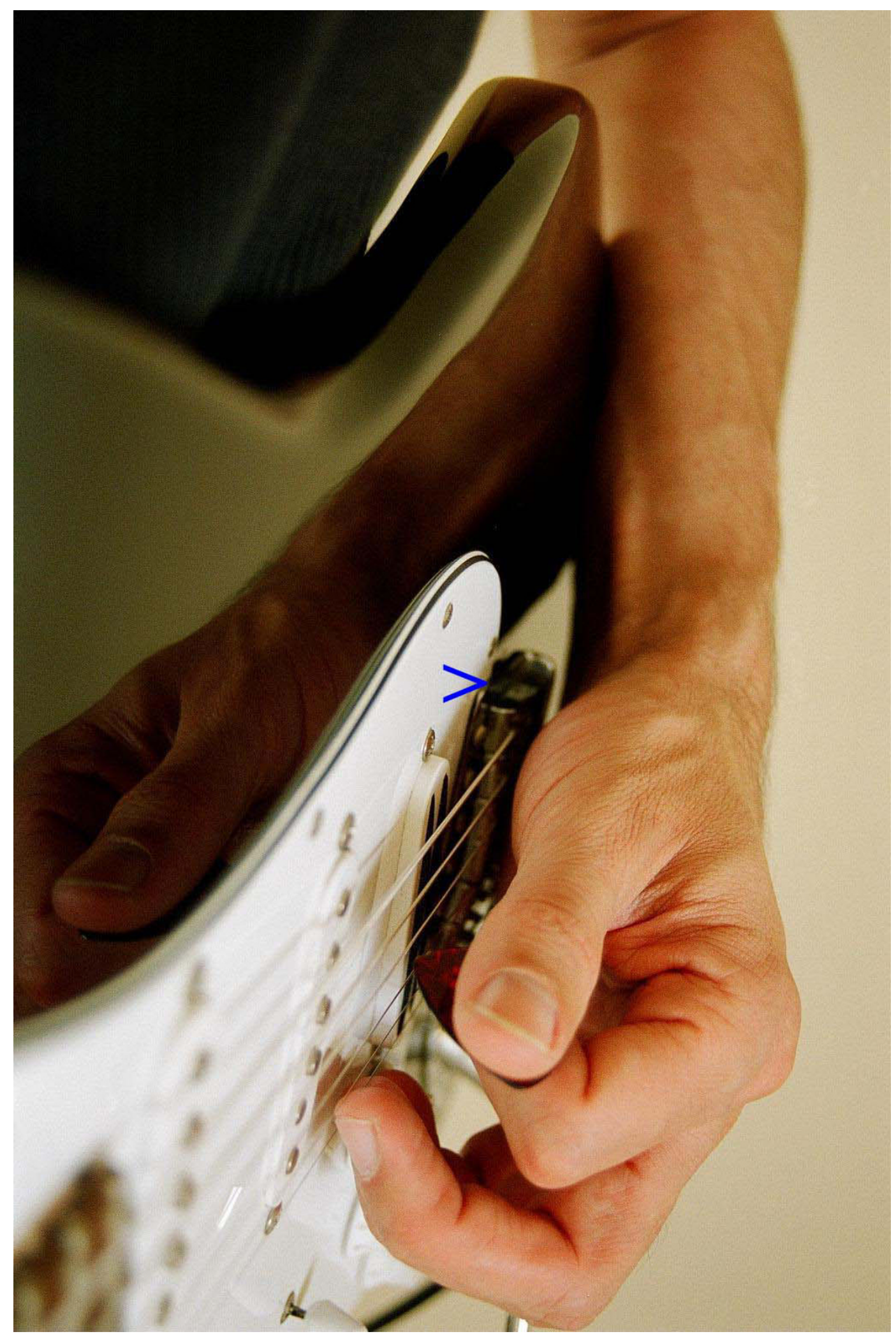

Figure 2

Intense skin contact with potentially chromium as well as nickel-sensitizing components on the strings and bridge (arrow head) of an electric guitar's body. 


\section{"Flautist's chin", "Clarinetist's cheilitis" etc}

In analogy to string players, woodwind and brass instrumentalists appear to be prone to develop irritant contact dermatitis on her lips and/or chin [70-74]. "Flautist's chin" has been described in a 32-year-old amateur flautist [70]. She presented with an eruption of acne-like lesions and hyperpigmentation confined to the central mid-portion of her chin, where she was in contact with her flute. Wetting of the chin with saliva or breath condensate was suspected as a predisposing factor, as this slipperiness could cause the player to increase the pressure of the flute against the skin [73]. Two separate reports of "clarinetist's cheilitis" have appeared in the literature [70,72]. Hindson [70], for example, reported three cases of an irritant contact dermatitis confined to the median area of the lower lip exactly underneath the reed of the clarinet. Results of extensive patch testing were negative. Friedman and Connolly [72] described the case of a 15-year-old clarinetist in whom erythema and scaling of the median portion of the lower lip developed. Again, results of extensive patch testing were negative. Both reports suggest that "clarinetist's cheilitis" may be caused by a combination of factors, including friction, local pressure, shearing forces, and occlusion [7]. It has to be stressed, however, that atopic diathesis is a commonly overlooked cause of cheilitis [28].

\section{Callosities and skin trauma}

A common and welcome skin condition experienced by almost all musicians at both amateur and professional level is the development of callosities on sites where the skin is repetitively irritated due to intense contact to certain parts of the instrument such as the strings of a guitar (Fig. 3). Thickening of the stratum corneum (Fig. 4) as well as the epidermis covers and protects the more vulnerable layers underneath from repeated stress and trauma [75]. Therefore, building and maintaining calluses is the aim of most instrumentalists, in particular string players [76]. Certain callosities may be considered as "occupational mark". Using the "thumb position", cellist's may develop calluses on their left thumbs. In contrast violinists usually develop calluses ("Garrod's pads") on the dorsal left second and third fingers over the proximal interphalangeal joints [77]. Depending on the technique callosities ("drummer's digit") are frequently observed in drummers on the lateral phalanx of the left ring finger [78]. Moreover calluses are also observed in wind instrumentalists such as clarinetists or oboe players. The affected characteristic area includes the mid portion of the upper lip $[28,79]$. Callosities of musicians only require treatment, if they are excessive or symptomatic. Excessive rhagadiform hyperkeratoses may occur in predisposed individuals, in particular in instrumentalists with psoriatic or atopic diathesis.
Frequently beginning string instrumentalists are plagued by eternally sore fingertips and traumatic blister formation. In sitar players, repeated stretching of strings with pressure may produce transverse depressions and scars on the pulp spaces of the fingers [80]. More severe skin trauma including erosions, blistering, and ulcerations may be observed in percussionists as well. Paronychia are important occupational hazards of instrumentalists such as pianists and harpists. Harpists are also prone to develop onycholysis and subungual haemorrhages. In horn players, a circumscribed atrophy of the upper lip as well as ischaemia of the lips and oral mucosa may occur [79]. Subcorneal bleeding analogous to the "talon noir" seen on the feet of runners can be observed under the calluses of musicians. Violinists may traumatize the skin of the jawline, producing scar formation and discoloration [81]. Apart from skin related trauma a variety of soft tissue and bony changes have been described in instrumentalists [82-86], for instance, acro-osteolysis in guitar players $[84,85]$ and "Satchmo's syndrome" - rupture of the orbicularis oris in trumpet players [86].

\section{Skin infections}

Most of the reported instrument-linked skin infections in musicians may be due to secondary infection of irritated and traumatized skin and/or transfer of contagious agents via instruments from one musician to another [87-92]. For example, string players with rhagadiform calluses or fiddler's neck may experience on the affected sites secondary pyoderma as well [87]. As mentioned in the previous paragraph, secondary paronychia may occur due to repeated skin trauma. Furthermore Kick et al. [88] recently described a trumpet player with perioral folliculitis barbae candidomycetica. However herpes labialis is more common in brass instrumentalists than in the population at large $[89,90]$. Large quantities of bacteria may be harbored on instruments, and hepatitis A, hepatitis B, Epstein-Barr virus, and cytomegalovirus may all be transmitted by saliva. Therefore sharing mouthpieces is not recommendable [92]. Human immunodeficiency virus (HIV) infection is more prevalent among performing artists than the population at large, but this virus is not thought to be transmitted through contact with saliva or sweat $[93,94]$.

\section{Miscellaneous disorders}

Black dermographism, a discoloration on the lower lips of flautists has also been observed [95]. A chemical reaction between the silver of the flute's mouthpiece and lotion containing sulfur and zinc oxide that she used for her perioral acne has been suggested the causative factor. Theoretically, black dermographism may occur on the face or hands of musicians, who play metal instruments, from other sources such as from liquid or powder make-up or from moisturizers $[95,96]$. Semple [97] proposed the 


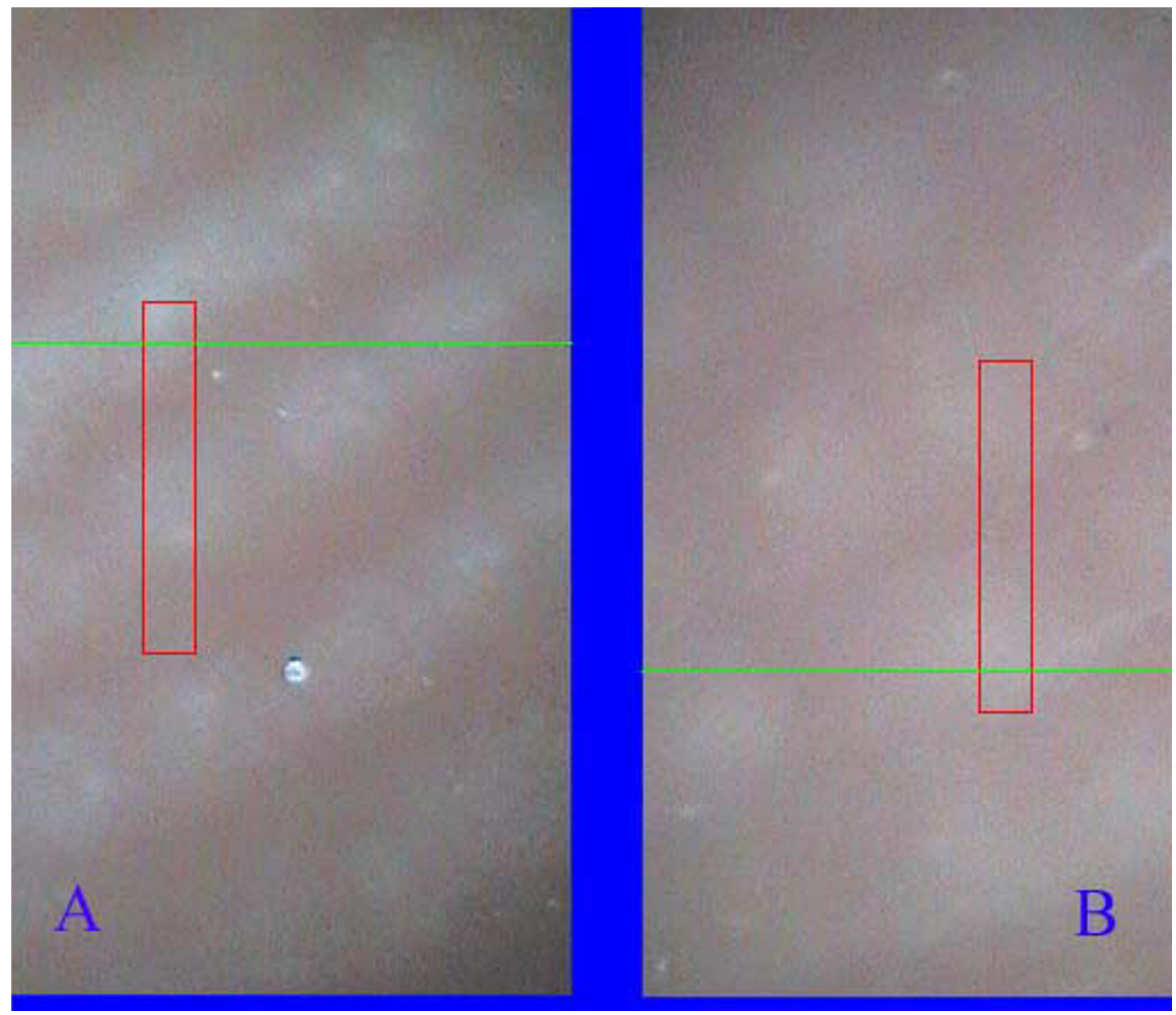

Figure 3

Video images (magnification, $\times 30$ ) of the ring fingers of an electric guitar player who uses for picking the plectrum technique as shown in Fig. IB. Images have been performed on the skin of the centre of the fingertips [A = left ring finger (picking hand); B = right ring finger (fretboard hand). Image of the ring finger of the fretboard hand (B) clearly demonstrates a clumsy and faded fingerprint structure as compared to the left ringer that is not used for playing.

term "guitar groin" in a 24-year-old classic guitarist who was admitted to the hospital with a deep vein thrombosis of the left calf and thigh. On examination, marked varicose veins were present in the left leg only. This patient practiced classic guitar four to six hours a day as he sat with the left leg fully flexed and with the guitar's belly compressing the medial aspect of the thigh. Varicosities and phlebothrombosis were thought to be due to prolonged compression of the long saphenous vein.
Furthermore Paget-Schroetter syndrome has previously been described in a viola player [98].

Emotional upset may lead to hyperhidrosis so severe it interferes with ability to operate musical instruments [5,7]. Hoppmann et al. [99] described a female pianist who switched from the piano to the flute because of severe localized palmar hyperhidrosis. If stage fright is the trigger for excessive sweating the use of beta blockers may 

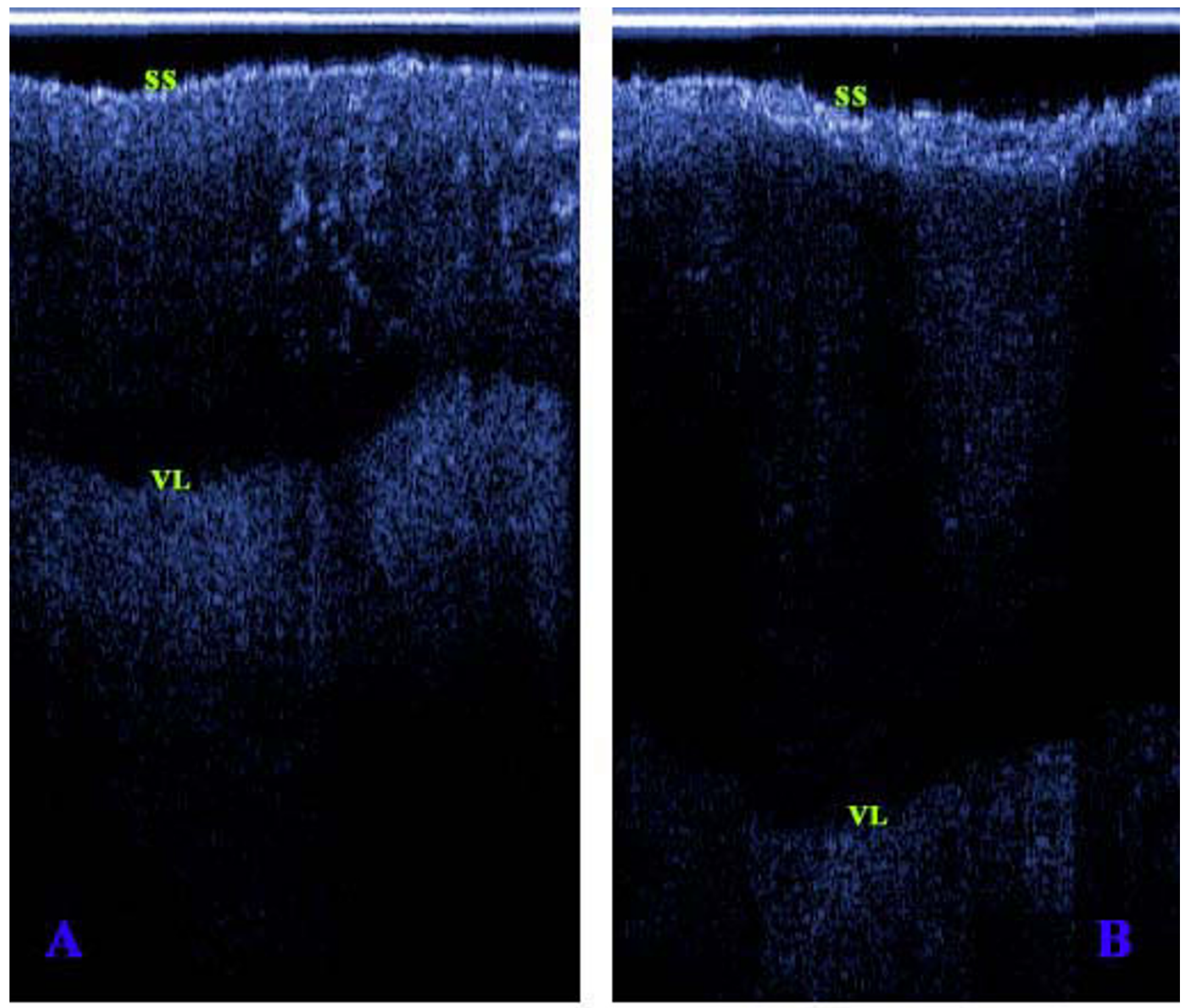

Figure 4

Two-dimensional imaging with optical coherence tomography in vivo (SkinDex 300, ISIS optronics GmbH, Mannheim, Germany) of the same sites as shown in Figure 2. The border between the cornified and living epidermis is clearly seen [75]. Hence the extent of the stratum corneum from skin surface (SS) to the border of the viable layer (VL) could easily be assessed. A significantly thicker stratum corneum has been observed on the right ring finger (B) as compared to the left ring finger (A) [mean values of 3 assessments on different sites: $274 \mu \mathrm{m}(\mathrm{A})$ vs $513 \mu \mathrm{m}(\mathrm{B})]$.

help to reduce sweat secretion. Topical aluminium salts, tab-water iontophoresis, and botulinum toxin injections include conservative therapy regimens. Any surgical therapy may involve a risk of deleterious effects on performance capability. Moreover xerostomia as well as hypersalivation can be disabling to wind players $[7,100]$.

\section{Conclusions}

Skin conditions may be a significant problem not only in professional instrumentalists, but also in musicians of all ages and ability. Although usually not life threatening they may lead to impaired performance and occupational hazard. Unfortunately, epidemiological investigations have exclusively been performed on orchestra musicians, though the prevalence of skin condition in other musician 
Table I: Collection of instrument-related allergic, irritant, and traumatic skin conditions that may occur in musicians

\begin{tabular}{|c|c|c|}
\hline Instrument & Allergic noxae & Irritant/traumatic noxae \\
\hline violin, viola & $\begin{array}{l}\text { allergic contact dermatitis to colophony, nickel, } \\
\text { propolis, chromium, exotic woods para- } \\
\text { phenylenediamine }\end{array}$ & $\begin{array}{l}\text { "fiddler's neck", Garrod's pads, finger dermatitis } \\
\text { and callosities }\end{array}$ \\
\hline cello, (contra) bass & $\begin{array}{l}\text { allergic contact dermatitis to nickel, para- } \\
\text { phenylenediamine colophony, propolis }\end{array}$ & $\begin{array}{l}\text { "cellist's chest", "cellist's knee" "cello } \\
\text { scrotum"(?), finger dermatitis and callosities }\end{array}$ \\
\hline $\begin{array}{l}\text { woodwind instruments (flute, clarinet } \\
\text { saxophone etc.) }\end{array}$ & $\begin{array}{l}\text { allergic contact dermatitis to nickel, exotic } \\
\text { woods, cane reeds }\end{array}$ & $\begin{array}{l}\text { "flautist's chin", "clarinetist's cheilitis" etc., lip } \\
\text { callosities }\end{array}$ \\
\hline brass instruments (trumpet, horn etc.) & allergic contact dermatitis to nickel, chromium & $\begin{array}{l}\text { cheilitis, lip callosities, facial soft tissue changes } \\
\text { (Satchmo's syndrome), lip atrophy and } \\
\text { ischaemia }\end{array}$ \\
\hline harmonica & allergic contact dermatitis to nickel, chromium & cheilitis \\
\hline guitar, bass guitar sitar etc. & $\begin{array}{l}\text { allergic contact dermatitis to nickel, chromium, } \\
\text { para-phenylenediamine }\end{array}$ & $\begin{array}{l}\text { "guitar nipple", finger dermatitis and callosities, } \\
\text { paronychia }\end{array}$ \\
\hline harp & allergic contact dermatitis to chromium & $\begin{array}{l}\text { finger dermatitis and callosities, paronychia, } \\
\text { onycholysis }\end{array}$ \\
\hline piano, keyboards & & finger dermatitis, paronychia, onycholysis \\
\hline drums, percussion & & $\begin{array}{l}\text { callosities ("drummer's digit), finger dermatitis, } \\
\text { skin trauma (blisters, ulceration etc.) }\end{array}$ \\
\hline
\end{tabular}

Table 2: Collection of instrument-related infectious and miscellaneous skin conditions that may occur in musicians

\begin{tabular}{|c|c|c|}
\hline Instrument & Infectious noxae* & Miscellaneous \\
\hline violin, viola & & $\begin{array}{l}\text { skin discoloration, Paget-Schroetter syndrome, } \\
\text { hyperhidrosis }\end{array}$ \\
\hline $\begin{array}{l}\text { woodwind instruments (flute, clarinet } \\
\text { saxophone etc.) }\end{array}$ & herpes labialis etc. & lip discoloration, impaired salivation \\
\hline brass instruments (trumpet, horn etc.) & herpes labialis etc., candida-folliculitis & impaired salivation \\
\hline harmonica & herpes labialis etc. & impaired salivation \\
\hline guitar, bass guitar sitar etc. & & "guitar groin", acro-osteolysis, hyperhidrosis \\
\hline piano, keyboards & & acro-osteolysis, hyperhidrosis \\
\hline
\end{tabular}

$*=$ secondary pyoderma of skin injuries not listed

groups, such as jazz and rock musicians, as well as amateur musicians is of interest as well [5-7,12]. The skin is important in the positioning and playing of a musical instrument. Hence a permanent more or less intense contact exists during playing between the instrument and the musician's skin. It is therefore not surprising that most of the reported skin disorders of instrumental musicians include a variety of allergic contact sensitizations, in particular to colophony, nickel, and exotic woods, and irritant skin conditions whose clinical appearance and localization are usually specific for the instrument used (e.g., "fiddler's neck"). Apart from common callosities and "occupational marks" more or less severe skin injuries may occur, in particular acute and chronic wounds including their complications such as bacterial infection. Herpes labialis infection may be a more common problem in wood wind and brass instrumentalists. By becoming familiar with the known conditions associated with spe- cific instruments, clinicians will be better able to diagnose and treat musicians who have skin problems affecting their performance (Tab. 1 and 2). On the other hand, awareness among musicians needs to be raised, as proper technique and conditioning may help to prevent affection of performance and occupational impairment.

\section{Abbreviations}

INCI: International Nomenclature for Cosmetic Ingredients

\section{Competing interests}

None declared.

\section{Authors' contributions}

TG conceived of this investigation including its methods and manuscript structure, performed the comprehensive literature search including data extraction and 
interpretation, and finished the paper. SB participated in the literature search and carried out skin imaging including measurements with optical coherence tomography. MF participated in the literature search and critically reviewed allergological aspects of the article. All authors read and approved the final manuscript.

\section{References}

I. Blum J, ed: Medizinische Probleme bei Musikern. Georg Thieme Verlag Stuttgart 1995.

2. Liu S, Hayden GF: Maladies in musicians. South Med J 2002 95:727-734.

3. Altenmüller E: Fokale Dystonien bei Musikern: Eine Herausforderung an die Musiker-Medizin. Musikphysiologie und Musikermedizin 1996, 3:29-40.

4. Fishbein M, Middlestadt SE, Ottati V, Strauss S, Ellis A: Medical problems among IC-SOM musicians: overview of a nationa survey. Med Probl Perform Art 1988, I: I-8.

5. Önder M, Cosar B, Öztas MO, Candansayar S: Stress and skin diseases in musicians: evaluation of the beck depression scale, general psychologic profile (the brief symptom inventory [BSI]), beck anxiety scale and stressful life events in musicians. Biomed Pharmacother 2000, 32:3II-3I5.

6. Nethercott JR, Holmes DL: Dermatologic problems of musicians. J Am Acad Dermatol 1991, 25:870.

7. Rimmer S, Spielvogel RL: Dermatologic problems of musicians. J Am Acad Dermatol 1990, 22:657-663.

8. Helm TN, Taylor JS, Adams RM, Fisher AA, Nethercott JR: Skin problems of performing artists. Am J Contact Derm 1993, 4:27-32.

9. Bork K: Stigmas, symptoms and diseases of the skin in musicians. Hautarzt 1993, 44:574-580.

10. Lombardi C, Bottello M, Caruso A, Gargioni S, Passalacqua G: Allergy and skin diseases in musicians. Allerg Immunol (Paris) 2003, 35:52-55.

II. Adams RM: Skin conditions of musicians. Cutis 2000, 65:37-38.

12. Önder M, Aksakal $A B$, Öztas MO, Gurer MA: Skin problems of musicians. Intl J Dermatol 1999, 38:192-195.

13. Ramirez MA, Eller J: The patch test in contact dermatitis. J Allergy 1930, I:489-495.

14. Wahlberg JE: Abietic acid and colophony. Contact Dermatitis 1978, 4:55.

15. Färm G: Contact allergy to colophony. Clinical and experimental studies with emphasis on clincal relevance. Acta Derm Venereol (Stockh) 1998, 20 I(Suppl): I-42.

16. Fisher AA: Allergic contact dermatitis in a violinist: the role of abietic acid - a sensitizer in rosin (colophony) as a causative agent. Cutis 198I, 27:466-473.

17. Fisher AA: Allergic contact dermatitis from musical instruments. Cutis 1993, $51: 75-76$.

18. Murphy J, Clark C, Kenicer K, Green C: Allergic contact dermatitis from colophony and Compositae in a violinist. Contact Dermatitis 1999, 40:334.

19. Angelini G, Vena GA: Allergic contact dermatitis to colophony in a violoncellist. Contact Dermatitis 1986, 15:108.

20. Peltonen $\mathrm{L}$ : Nickel sensitivity in the general population. Contact Dermatitis 1979, 5:27-32.

21. Basketter DA, Briatico-Vangosa G, Kaestner W, Lally C, Bontinck W]: Nickel, cobalt and chromium in consumer products: a role in allergic contact dermatitis? Contact Dermatitis 1993, 28:15-25.

22. Inoue A, Shoji A, Fujita T: Flautist's chin. Br J Dermatol 1997 , 136: 147

23. Nakamura $M$, Arima $Y$, Nobuhara $S$, Miyachi $Y$ : Nickel allergy in a trumpet player. Contact Dermatitis 1999, 40:219-220.

24. Marshman G, Kennedy CTC: Guitar-string dermatitis. Contact Dermatitis 1992, 26:134.

25. Pincelli C, Motolese A, Pincelli L: Fiddler's neck and nickel dermatitis. Contact Dermatitis 1986, I3:37.

26. Tennstedt D, Cromphaut P, Dooms-Goossens A, Lachapelle JM: Dermatoses of the neck affecting violin and viola players ("fiddler's neck") and contact dermatitis. Derm Beruf Umwelt 1979, 27:165-169.

27. Fisher AA: Allergic contact dermatitis from musical instruments. Cutis 1993, $51: 75-76$.
28. Freeman S, Stephens R: Cheilitis: analysis of $\mathbf{7 5}$ cases referred to a contact dermatitis clinic. Am J Contact Dermat 1999, 10:198-200.

29. Machácková J, Pock L: Occupational nickel dermatitis in a cellist. Contact Dermatitis 1986, I5:4|-42.

30. Thomas P, Tueff F, Przybilla B: Cheilitis due to nickel contact allergy in a trumpet player. Contact Dermatitis 2000, 42:35I-352.

31. Moreno JC, Gata IM, Garcia-Bravo M, Camacho FM: Fiddler's neck. Am J Contact Dermat 1997, 8:39-42.

32. Hausen BM: Incidence and significance of toxic and allergic contact dermatitis caused by Macherium Scleroxylum Tul (Pao ferro), a substitute wood for palisander. Hautarzt 1982, 33:32I-328.

33. Hausen BM, Munster G: Cocobolo-Holz, ein vergessenes Ekzematogen? Neuere Erkenntnisse über das Hauptallergen des Cocobolo-Holz (Dalbergia sp.). Dermatosen 1983, 31: I I0-I I7.

34. Hausen BM, Bruhn G, Koenig WA: New hydroxvisoflavans as contact sensitizers in cocus wood Brya ebenus DC (Fabaceae). Contact Dermatitis 199|, 25: |49-155.

35. Hausen BM, Mau HH: Contact allergy with a rosewood violin chin rest. Derm Beruf Umwelt 1979, 27:18-20.

36. Hausen BM: Chin rest allergy in a violinist. Contact Dermatitis 1985, I 2:178-180.

37. Piletta PA, Hausen BM, Pasche-Koo F, French LE, Saurat JH, Hauser $\mathrm{C}$ : Allergic contact dermatitis to East Indian rosewood (Dalbegia latifolia Roxb.). J Am Acad Dermatol 1996, 34:298-300.

38. Haustein UF: Violin chin rest eczema due to east-Indian rosewood (Dalbergia Latifolia ROXB). Contact Dermatitis 1982, 8:77-78.

39. Schwartz L, ed: Occupational Skin Diseases. Lea \& Fabiger Philadelphia 1957:163.

40. Inoue A, Shoji A, Yashiro K: Saxophonist's cane reed cheilitis. Contact Dermatitis 1998, 39:37.

4I. McFadden JP, Ingram MJ, Rycroft RJG: Contact allergy to cane reed in a clarinetist. Contact Dermatitis 1992, 37: I I7.

42. Lerner C: Cheilitis caused by Italian reed. Urol Cutan Rev 194I, 45: $195-196$

43. Van der Wegen-Keijser MH, Bruynzeel DP: Allergy to cane reed in a saxophonist. Contact Dermatitis I991, 25:268-269.

44. Lieberman HD, Fogelman JP, Ramsay DL, Cohen DE: Allergic contact dermatitis in a violin maker. J Am Acad Dermatol 2002, 46(Suppl 2):S30-S3I.

45. Monti M, Benti E, Carminanti G, Cusini M: Occupational and cosmetic dermatitis from propolis. Contact Dermatitis 1983, 9:163.

46. Hausen BM, Wollenweber E, Senff H: Propolis allergy. Origin, properties, usage and literature review. Contact Dermatitis I987, 17:163-170

47. Machácková J: The incidence of allergy to propolis in 605 consecutive patients patch tested in Prague. Contact Dermatitis 1988, 18:210-212.

48. Bork K: Allergic contact dermatitis on a violinist's neck from para-phenylenediamine in a chin rest stain. Contact Dermatitis 1993, 28:250-25।.

49. O'Hagan $\mathrm{AH}$, Bingham EA: Cellist's finger dermatitis. Contact Dermatitis 200I, 45:319.

50. Buckley DA, Rogers S: 'Fiddler's fingers': violin-string dermatitis. Contact Dermatitis 1995, 32:46-47.

5I. Peachey RDG, Matthews CAN: "Fiddler's neck". Br J Dermatol 1978, 98:669-674.

52. Oga A, Kadowacki T, Hamanaka S, Sasaki K: Dystrophic calcinosis cutis in the skin below the mandible of a violinist. $\mathrm{Br} J$ Dermatol 1998, 139:940-941.

53. Brun P, Baran R: Un acne mechanique ceconnue: la dermite du cou des violinistes. Ann Dermatol Venereol I 984, I I I :24 I-245.

54. James J: Fiddler's neck or chin: A matter for attention. J Violin Soc Am 1992, I2:| 197-20।.

55. Kaufman $B H$, Hoffman AD, Zimmerman D: Fiddler's neck in a child. J Pediatr 1988, I I 3:89-90.

56. Stern JB: The edema of fiddler's neck. J Am Acad Dermatol 1979, I:538-540.

57. Lachappelle JM, Tennstedt D, Cromphaut P: Pseudofolliculitis of the beard and "fiddler's neck.". Contact Dermatitis 1982, 7:247.

58. Rajna E: Tackling violinist's neck. Med World 1967, 105:87.

59. Zina AM, Anunziata M: II "callo" del violista. Giornale Ital Dermat e Venereol 198I, I 16:31.

60. Carabias E, Dhimes $\mathrm{P}, \mathrm{De}$ Augustín P: Nodular cervical induration in a violinist. Acta Cytol 1996, 40:130I-1303. 
61. Blum J, Ritter G: Violinists and violists with masses under the left side angle of the jaw known as fiddlers neck. Med Probl Perform Art 1990, 5:155-160.

62. Rietschel RL, Fowler JF, eds: Fisher's contact dermatitis. Williams \& Wilkins Baltimore 1995.

63. Mandell HN: Cellist's chest. N Engl J Med 1962, 266:348.

64. Murphy JM: Cello scrotum. Br Med J 1974, 2:335.

65. Shapiro PE: "Cello scrotum" questioned. J Am Acad Dermatol 1991, 24:665.

66. Curtis P: Guitar nipple. Br Med J 1974, 2:226.

67. Thomas JM: Musical bumps. Br Med J 1974, 2:504.

68. Melia NP: Musical bumps. Br Med J 1974, 2:669.

69. Ross DG: Musical bumps. Br Med J 1974, 2:669.

70. Hindson TC: Clarinetist's cheilitis. Br Med J 1978, 2:1295.

7I. Dahl MG: Flautist's chin: a comparison to fiddler's neck. Br Med J 1978, 2:1023.

72. Friedman SJ, Connolly SM: Clarinetist's cheilitis. Cutis 1986, 38: $183-184$.

73. Gardner LD: Flautist's chin. Br Med J 1978, 2:1295.

74. Jago JD: Medical and dental problems of musical instruments. BrMed J 1978, 2:1295.

75. Fruhstorfer $\mathrm{H}$, Abel $\cup$, Gerthe $C D$, Knüttel $A$ : Thickness of the stratum corneum of the volar fingertips. Clin Anat 2000, 13:429-433.

76. Burr T: Caring for calluses. Acoustic Guitar 1992, 3:35-37.

77. Bird HA: Development of Garrod's pads in the fingers of a professional violonist. Ann Rheum Dis 1987, 46:169-170.

78. Signore RJ: Dermatologic problems of musicians. J Am Acad Dermatol 1991, 24:321.

79. Landeck $\mathrm{E}$ : Lippenläsionen bei Blechblasinstrumentalisten. Dermatol Monatsschr 1974, 160:762-765.

80. Kanwar AJ, Kaur S: More dermatologic problems of musicians. J Am Acad Dermatol 1991, 24:321-322.

8I. Goldstein LJ: When violin scars jaw, try custom chin rest. Dent Surv 1968, 44:48.

82. Fisher AA: Dermatitis in a musician. Part III: Injuries caused by specific musical instruments. Cutis 1998, 62:26|-262.

83. Fisher AA: Dermatitis in a musician. Part II: injuries to skin, soft tissue and bone from musical instruments. Cutis 1998 , 62:2|4-2|5.

84. Baran R, Tosti A: Occupational acro-osteolysis in a guitar player. Acta Derm Venereol (Stockh) 1993, 73:64-65.

85. Destouet JM, Murphy WA: Guitar player acro-osteolysis. Skel Radiol 1981, 6:275-277.

86. Planas J: Rupture of the orbicularis oris in trumpet players (Satchmo's syndrome). Plast Reconstr Surg 1982, 69:690-693.

87. Sebastian G: Chronic pyoderma as a rare complication of the violonist's callosity. Dermatol Monatsschr 1973, 159:733-738.

88. Kick G, Korting HC: Debilitating folliculitis barbae candidomycetica in a trumpeter: successful treatment with fluconazole. Mycoses 1998, 41:339-342.

89. Barkvoll $P$, Attramadal A: Recurrent herpes labialis in a military brass band. Scand I Dental Res 1987, 5:256-258.

90. Barkvoll P, Attramadal A, Rolla G: Musicians and herpes. Tidsskr Nor Laegeforen (Norw) 1987, 107:1036-1037.

91. Fisher AA: Dermatitis in a musician. Part IV: Physiologic, emotional and infectious problems in musicians. Cutis 1999 63:13-14.

92. Bryan $\mathrm{AH}$ : Band instruments harbor germs. Music Educators Journal 1960, 46:84-85.

93. Calabrese LH: AIDS in the performing arts. Med Probl Perform Art 1987, 2:113-116.

94. Brockmeyer NH, ed: HIV-Infekt: Epidemiologie, Prävention, Pathogenese, Diagnostik, Therapie, Psychosoziologie. Springer Berlin 2000:1-918.

95. Koransky JS: Dermatologic problems of musicians: iatrogenic black dermographism. J Am Acad Dermatol 1994, 31:5 I 9.

96. Fisher AA: Black dermographism: mechanism for formation of black color. Cutis 2004, 52:17-17.

97. Semple R, Gillingham J: Musical bumps. Br Med J 1974, 2:504.

98. Reina NJ, Honet JC, Brown OW: Paget-Schroetter syndrome in a viola player. Med Probl Perform Art 1988, 3:24-25.

99. Hoppmann RA, Burke WA, Patrone NA: Hyperhidrosis in the performing artist. Med Probl Perform Art 1988, 3:60-62.

100. Dettmann CE: Suppression of salivation in wind-instrument players with scopolamine. $N$ Engl J Med 1984, 3 I 0: 1396.

\section{Pre-publication history}

The pre-publication history for this paper can be accessed here:

http://www.biomedcentral.com/1471-5945/4/3/prepub
Publish with BioMed Central and every scientist can read your work free of charge

"BioMed Central will be the most significant development for disseminating the results of biomedical research in our lifetime. "

Sir Paul Nurse, Cancer Research UK

Your research papers will be:

- available free of charge to the entire biomedical community

- peer reviewed and published immediately upon acceptance

- cited in PubMed and archived on PubMed Central

- yours - you keep the copyright 